\title{
PARENTING STYLES OF ADOLESCENTS' PARENTS IN KOSOVO AND METOHIJA ${ }^{3}$
}

\begin{abstract}
Based on the summary of the findings of research on parenting styles, which was conducted on the sample of adolescents living or studying in Kosovo and Metohija, the paper aims to present predominant parenting styles and foresee further development of certain traits analysed in adolescents. Furthermore, not only does it aim to specify the direction of certain surveys on this issue in the future but also put forward recommendations relating to organizing prevention and intervention programmes intended for parents and adolescents. After gaining an insight into the findings of surveys presented (conducted between 2012 and 2019), the following predominant parenting style stood out among the adolescent respondents (more than 2200 adolescents, i.e., high school students and undergraduates aged between 16 and 24): the cold parenting style is prevalent in fathers in every survey presented, while the warm parenting style is prevalent in mothers, in addition to the cold parenting attitude. The research on parenting styles has yielded certain correlations and differences, as well as the findings highlighting the possibility of predicting development of specific traits in adolescents depending on parenting styles. The conclusions are
\end{abstract}

\footnotetext{
miljana,pavicevic@pr.ac.rs

jelena.minic@pr.ac.rs

3 This paper is the result of the research conducted within the project III 47023 "Kosovo and Metohija between National Identity and European Integration" funded by the Ministry of Education, Science and Technological Development of the Republic of Serbia.

This paper was submitted on May $6^{\text {th }}, 2021$ and accepted for publication at the meeting of the Editorial Board held on November 16 ${ }^{\text {th }}, 2011$.
} 
arrived at have contributed to producing recommendations on how future surveys are to be organized and conducted.

The recommendations relating to working with parents are as follows: organizing educational seminars for parents for the sake of their familiarizing with and learning about quality parenting styles. These educational seminars should involve acquisition communication skills with the aim of more effective communication and better relationship between parents and adolescents. Moreover, providing families with counselling is recommended with a view to strengthening capacities for cooperation with parents in terms of their parenting styles and child care. It is of paramount importance to exert influence on fathers, whose education would enhance the level and quality of their involvement in parenting. Involving parents in further research is imperative, with the aim of comparing the findings relating to parents' standpoints and their children, and examining the relation among parenting styles, age, and a range of family variables.

KEYWORDS: parenting styles; parents; high school students; undergraduates.

INTRODUCTION

There are diverse terms in literature describing parents' treatment of their child (children): parenting attitudes, parenting styles, parenting actions, etc. Relationship between them can be outlined through a hierarchical model, with parenting actions at the bottom of it, followed by parenting attitudes, and parenting styles at the top of it (Matejević, 2007). Therefore, the term 'parenting style' is the most appropriate one, as it encompasses parenting actions, parenting attitudes, as well as relationship between parents and their children. The formation of parenting style begins quite early, and lasts throughout entire childhood and adolescence (Todorović, 2005). It is defined as a relatively consistent way of parental behaviour, which establishes relationship with children (Matejević, 2007), thus comprising the essence of parenting, and preserving its consistency (Todorović, 2005).

The majority of papers by researchers in Serbia (Genc, 1994; Mihić et al., 2006; Kodžopeljić et al., 2008) predominantly deal with a twodimensional parenting style model, i.e. Schaefer's model (Schaefer, 1959, according to Piorkowska-Petrović, 1991; Matejević, 2007), which comprises two dimensions: the affective dimension (emotional relationship between parents and children with the positive-negative poles: warm and cold parenting style) and the controlling one 
(psychological and physical freedom of children allowed, as well as their independence, with the poles: permissive and restrictive parenting style) (Schaefer, 1959, according to Piorkowska-Petrović, 1991; Matejević, 2007). The combination of extreme poles of the two dimensions yields four parenting styles: warm-permissive, cold-permissive, warm-restrictive and cold-restrictive parenting style. Each of the aforementioned parenting styles affects children, development of their personality, independence and relationship with their parents (Čudina-Obradović \& Obradović, 2006; Matejević, 2007; Kodžopeljić, 2009; Opsenica-Kostić, 2012). In 1967, Baumrind (1968) reassessed Schaefer's model and defined the three parenting styles: authoritarian (strict), authoritative (democratic) and permissive (lenient). The authoritarian parenting style entails strict parental control, less warmth, strict and domineering behaviour, where children are expected to be obedient, which corresponds to the cold-restrictive parenting style in Schaefer's model (Matejević, 2007). Authoritative parents make demands and establish clear rules and guidelines for conduct, explaining the reason for rules to children. Parental authority exists, atmosphere in the family is warm, democratic, and emotional, and children have a sense of belonging and feel they are appreciated by their parents, which corresponds to the warm-restrictive parenting style in Schaefer's model (Matejević, 2007). The permissive parenting style entails warm and emotional relationship with children, devoid of rules and discipline, children's whims are excessively gratified, and parents are incapable of maintaining control over children's behaviour. This style corresponds to the warm-permissive parenting style in Schaefer's model (Matejević, 2007). In the course of research conducted later, Baumrind added uninvolved parenting style to her parenting style model (Baumrind \& Thompson, 2002), which implies complete indifference to children's needs, children are left to their own devices, firm boundaries and rules are non-existent, including warmth of the family. This corresponds to the cold-permissive parenting style in Schaefer's model (Matejević, 2007).

This paper reviews the findings of research on parenting styles conducted from 2012 to 2019 on the sample of more than 2200 adolescents (high school students and undergraduates), aged between 16 and 24, of Serbian nationality who live or study in Kosovo and Metohija. In all reviewed surveys, where adolescents evaluated parenting styles of their parents, Schaefer's model was applied, which was operationalized through score on Parenting Style Evaluation 
Scale (Kodžopeljić, 2009). Baumrind's parenting style model, which was operationalized through score on PSDQ - Parenting Styles and Dimensions Questionnaire, was also used (Robinson et al., 2001). The research reviewed aimed at determining a predominant parenting style, predictive power of parenting styles with regard to predicting: authoritarianism, satisfaction with family and life, self-concept, interpersonal orientation, ethnocentrism, personality traits, self-efficacy and personal well-being in adolescents. The data were examined using descriptive statistics, correlation and regression analysis, and t-test.

\section{REVIEW OF RESEARCH AND DISCUSSION OF FINDINGS}

This section of the paper will outline the research conducted by the authors, beginning with the first research on this issue conducted in 2012 onwards to the most recent one, conducted in 2019.

The research conducted by Pavićević (2012) aimed at determining the relation between parenting styles of parents and authoritarianism of adolescents ( $\mathrm{N}=242)$, using the Authoritarianism Questionnaire (Mihić et al., 2009). The findings have indicated that a predominant parenting style of both parents was cold-restricitve and that there was a positive correlation between the cold-restrictive parenting style of father and mother with authoritarianism of adolescents. Based on the findings obtained, it all points to the conclusion that parents who sternly impose rules offering no explanation and insist on their children's blind obedience, may conduce to development of inflexible attitude in adolescents-tendency toward not re-evaluating actions and demands of an authoritywhich makes them extremely obedient and hyper-adjusted.

The research conducted by Pavićević and Tomović (2012) aimed to determine a predominant parenting style, as well as correlation and differences in parenting styles vis-a-vis gender of adolescents $(\mathrm{N}=122)$. The findings have shown that the predominant parenting style of both parents was cold-restrictive, and that male adolescents, unlike female ones, evaluated their fathers as colder and more restrictive. The findings obtained have led us to the conclusion that restrictions and prohibitions imposed by parents on adolescents sometimes might be experienced as a reflection of their 
parents' coldness and control, whereas the differences obtained in terms of gender were expected, in accordance with previous research and the process of gender identity development (Opačić et al., 1995). In the course of this process, male adolescents display a tendency toward espousing their father's value system (positive identification), whereas female adolescents tend to do the opposite (negative identification).

The survey carried out by Pavićević and Krstić (2013) strove to examine the correlation between parenting styles and adolescents' satisfaction with family $(\mathrm{N}=212)$, correlation with their family's economic circumstances and differences in terms of gender. The findings have shown that adolescents perceive fathers as cold-restrictive, whereas mothers are perceived as warm-restrictive, and that male adolescents, unlike female ones, perceive their fathers' parenting style as colder. Furthermore, the findings have indicated that the more warm-permissive parents are, the more satisfied adolescents will be with their family.

The survey undertaken by Pavićević and Minić (2014) examined the correlation between parenting styles and certain aspects of adolescents' self-concept ( $\mathrm{N}=179)$ using the Self-Concept Examination Scale, the so-called Self-Bezin Scale (Bezinović, 1988). The findings have shown that adolescents perceive their parents as cold-restrictive. The affective dimension of parenting styles proved to be a significant predictor of self-concept vis-à-vis control dimension. Flexibility in behaviour, establishing rules and making demands for their obedience are less significant to the development of self-concept in adolescence as compared to emotional involvement and acceptance from parents. Parenting styles of fathers proved to be significant predictors of self-concept as compared to parenting styles of mothers, and the warm parenting style of both parents is more striking in families living in straitened circumstances. The findings obtained are important bearing in mind the fact that father's continued presence, competence, and emotional involvement is closely connected with more favourable conditions for development- the family atmosphere, the family dynamics (Mihić, 2005; Mihić et al., 2006; Zotović et al., 2008), and child development (Pleck \& Masciadrelli, 2004).

The survey undertaken by Pavićević and Petrović (2016) aimed to assess the effects of parenting style in a family on development of ethnocentrism in adolescents $(\mathrm{N}=345)$ using the Ethnocentrism Evaluation Scale (Šram, 2010). The findings have demonstrated that 
adolescents perceive their parents as predominantly cold-restrictive. Parenting styles of mothers are more significant predictors of ethnocentrism. The findings obtained can be explained as the result of specific style of upbringing in Kosovo and Metohija, such as predominantly patriarchal culture (Zlatanović, 2012, Milovanović, 2014), which implies peculiar lifestyle, specific ideology and value system, with distinct differences as to how fathers and mothers treat their children. (Trebješanin, 2008). Fathers advocate work ethics, discipline and non-permissiveness, they are serious-minded and reserved to children, whereas mothers spend more time with children, taking care of them, and exerting stronger influence on their development and attitudes.

The survey conducted by Pavićević and Stojiljković (2016) examined the predictive power of parenting styles in predicting interpersonal orientation-certain aspects of philanthropic and misanthropic orientation-in adolescents $(\mathrm{N}=238)$ using the Interpersonal Orientation Scale (Bezinović, 2002). It was found that the perceived restrictive parenting style of mothers accounts for $5 \%$ variance of need for people as an aspect of philanthropic orientation, which reflects adolescents' tendency to counterbalance their discontent with relationship with their parents by seeking support and advice from their peers. Also, the perceived warm-restrictive parenting style of mothers accounts for $8 \%$ of need for friendship. This kind of parenting practice is conducive to development of an energetic, gregarious, self-confident, and brisk child who is achievement-oriented (Mitić, 2011). The emotionally aloof and cold parenting style of mothers represents an important predictor of distrust and accounts for $11 \%$ variance of distrust, whereas the warm parenting style of mothers leads to less inclination of respondents toward social isolation (15\% variance), as aspects of misanthropic orientation. Recurrent family conflicts are among the factors causing problematic behaviour and anxiety in social interaction (Mc Hale et al., 2000, according to Mihić et al., 2006). Cold and emotionally aloof parents cause their child to feel solitary and shun company (Mitić, 2011), to be hostile toward social environment, prone to conflicts, unhappy and unstable (Matejević, 2007), to be unresponsive, distrustful, inclined to alienation (Majstorović et al., 1999; Matejević, 2007) and dissatisfied with themselves (Kodžopeljić et. al., 2008).

The survey conducted by Pavićević and Stoševski (2019a) examined the predictive power of prenting styles in predicting adoles- 
cents' interpersonal orientation and satisfaction with lifestyle $(\mathrm{N}=175)$ using Bezinović's Interpersonal Orientation Scale (IO) and Penezić's Life Satisfaction Scale, 2002. The findings have shown that parenting styles account for $28,1 \%$ variance of philanthropic orientation in adolescents, while the restrictive parenting style of fathers and low-level permissive parenting styles of motheres were singled out as significant predictors. This creates the impression that strict control of fathers causes adolescents to seek support and advice from their peers and thus counterbalance their unsatisfactory relationship with their father. Also, parenting styles account for $40,3 \%$ variance of adolescents' misanthropic orientation, and one of the significant predictors is the restrictive parenting style of mothers. The restrictive parenting style of mothers causes a child to feel solitary (Mitić, 2011), hostile toward social environment, prone to conflicts, unhappy and unstable (Matejević, 2007). Parenting styles of both parents account for $20 \%$ variance of adolescents' satisfaction with lifestyle, and one of the important predictors is also mother's restrictive parenting style. When mothers exert less control over their children, adolescents will display a higher level of satisfaction with their lifestyle.

The survey conducted by Pavićević and Stoševski (2019b) examined the predictive power of evaluated parenting styles in predicting adolescents' personality traits $(\mathrm{N}=175)$ using Personality Inventory NEO PI R (Đurić-Jočić et al., 2004). The findings have shown that the restrictive parenting style of mothers is a significant predictor of neuroticism (32\% variance), openness to experience $(25,5 \%$ variance) and conscientiousness (17\% variance) in adolescents. A parent whose parenting style is restrictive imposes many rules and prohibitions upon a child, sternly expecting them to be obeyed, and administering punishment in case of violation of rules. This kind of environment is conducive to arousal of profound, conflicting emotions, maladjustment to new circumstances and lack of resistance to stress (Đurić-Jočić et al., 2004). The findings have indicated that the cold parenting style of fathers gives rise to adolescents' extroversion (28\% variance), whereas the warm parenting style of fathers gives rise to adolescents' openness to experience ( $25 \%$ variance). It is precisely this cold emotional relationship fathers have with their children that can cause a child to feel and express the need for excitement and encouragement, the need for company involving a large number of people, the need for experiencing positive emotions (joy, love and excitement) 
(Đurić-Jočić et al., 2004), so that children could counterbalance cold emotional relationship their fathers have with them. The affective dimension of parenting style of fathers (warm and cold) facilitates adolescents' openness to change, versatility, creativity, experiencing intense emotions and tolerance.

The survey undertaken by Pavićević (2019) examined the predicitve power of parenting styles (authoritarian, authoritative and permissive) in predicting self-efficacy of adolescents (social, academic and emotional). High-level authoritativeness and low-level permissiveness of fathers, as well as high-level authoritativeness of mothers are significant in terms of predicting social (19,9\% variance) and emotional (16,9\% variance) self-efficacy of adolescents. Parenting styles account for $24,4 \%$ variance of academic self-efficacy, and no dimension of parenting styles made a statistically significant contribution. When parents are perceived as supportive parents who explain reasons behind their demands and expectations, rules, relationship between behaviour and its consequences, and reasons why abiding by rules is important, and who are emotionally close to their children at the same time, adolescents will achieve both social and emotional self-efficacy (Egeland et al., 1993).

The survey conducted by Pavićević and Stojiljković (2019) strove to examine the predictive power of parenting styles (authoritarian, authoritative and permissive) in predicting adolescents' subjective well-being $(\mathrm{N}=270)$. It was found that the authoritative parenting style of both parents accounts for $20 \%$ variance of adolescents' subjective well-being. Authoritative parents develop emotionally close relationship with their children, being supportive and respectful of their children's opinion and personality, thereby enabling them to develop positive affectivity, positive outlook on life or subjective well-being (Matejević \& Todorović, 2012).

CONCLUSION After reviewing the above-mentioned surveys, the following conclusions can be drawn:

- Four surveys found that the cold-restrictive parenting style is predominant in both parents, and one survey found that fathers' parenting style is cold-restrictive, whereas mothers' parenting style is warm-permissive.

- Male adolescents, unlike female ones, perceive their fathers' parenting style as colder. 
- The cold-restrictive parenting style might be conducive to very marked authoritarianism in adolescents.

- The warm-permissive parenting style enhances adolescents' satisfaction with their family.

- Parenting styles of fathers are more significant for the development of adolescents' self-concept as compared to mothers' parenting styles.

- Parenting styles of mothers are more significant for the development of adolescents' ethnocentrism as compared to parenting styles of fathers.

- The cold-restrictive parenting style of mothers conduces to misanthropic interpersonal orientation of adolescents, whereas the warm-permissive parenting style of mothers conduces to philanthropic one.

- The warm parenting style of mothers causes adolescents to feel more satisfied with their lifestyle.

- The restrictive parenting style of mothers might be conducive to neuroticism, openness and conscientiousness of adolescents, while the cold parenting style of fathers gives rise to extroversion, and the restrictive parenting style of fathers gives rise to adolescents' openness.

- Authoritative parents might contribute to adolescents' experience of self-efficacy and subjective well-being.

It is strongly recommended that further research on parenting styles should be focussed on the examination of the relationship among parenting styles, age, and a range of family variables. Furthermore, involving parents in research to be conducted in the future is also recommended, with a view to obtaining data on parenting styles of parents themselves and comparing the findings with the perception of their children. Also, practitioners are advised to organize educational seminars for parents to learn about adequate parenting styles and more effective communication, with the aim of improving the relationship between parents and their children. Families should also receive counselling for the purpose of strengthening cooperation capacities with parents regarding their parenting style and care for children. (Mihić et al., 2009). Exerting influence on fathers is of the essence, so that their continued presence, competence, and emotional involvement could enhance the conditions for children's development, family atmosphere, as well as the family dynamics (Grubor et al., 2009). 
The findings obtained should be interpreted considering the relatively specific sample in view of age and residence. Namely, the sample in the surveys reviewed consisted of adolescents living in Kosovo and Metohija where the traditional family still persists, with the gender distribution of household- and care work. Mothers have a central role as child carers expected to „rear them very well", and they are the ones who are supposed to set limits, impose prohibitions and control, whereas fathers serve a key role as breadwinners, which implies that they are less involved in child care. It is important to emphasize that the respondents live in a limited and frequently hostile social environment, which prevents them from satisfying their basic need for safety. Also, what should be taken into consideration is the specific quality of the respondents' development during adolescence, which is, among other things, characterized by rebellion against authority, pressing need for forging their own identity and a sense of uniqueness, which is sometimes combined with their fierce resistance to everything adults believe is worthwhile, and this can lead to identity crisis and confusion of roles (Todorović, 2005).

Baumrind D. (1968). Authoritarian vs. Authoritative Parental Control. Adolescence, 3 (11), 255-272.

Baumrind, D. \& Thompson, A. R. (2002). The Ethics of Parenting. In: M. Bornstein (Ed.), Handbook of Parenting, 5. Practical Issues in Parenting. Mahwah, New Jersey London: LEA.

Bezinović, P. (1988). Prikaz skala za mjerenje nekih aspekata samopoimanja. Praktikum iz kognitivne i bihejvioralne terapije. Zagreb: Filozofski fakultet.

Bezinović, P. (2002). Skala interpersonalne orijentacije - IO. U: K. Lacković-Grgin, A. Proroković, V. Ćubela, Z. Penezić (ur.), Zbirka psihologijskih skala i upitnika. Svezak 1 (69-72). Zadar: Filozofski fakultet.

Đurić-Jočić, D., Džamonja-Ignjatović, T., Knežević, G. (2004). NEO PI-R, Primena i interpretacija. Beograd: Centar za primenjenu psihologiju društva psihologa Srbije.

Egeland, B., Carlson, E., Sroufe, L. A. (1993). Resilience as process. Development and Psychopatology, 5 (4), 517-528.

Genc, L. (1994). Percepcija zastupljenosti vaspitnih postupaka roditelja u zavisnosti od pola, uzrasta, socioekonomskog statusa i školskog uspeha adolescenata. U: Đ. Đurić (ur.), Ličnost u višekulturnoj sredini (15-24). Novi Sad: Filozofski fakultet, Odsek za psihologiju. 
Grubor, S. Mihić, I., Zotović, M., Petrović, J. (2009). Relacije self-koncepta adolescenata i procenjenih vaspitnih stilova njihovih roditelja. Pedagoška stvarnost, LV (5-6), 622-635.

Jovanović, V. i Brdarić, D. (2008). Kratka skala subjektivnog blagostanja. Neobjavljeni manuscript. Novi Sad: Univerzitet u Novom Sadu.

Kodžopeljić, J., Pekić, J., Genc, A. (2008). Relacije između vaspitnih stavova roditelja i autoritarnosti dece. Pedagoška stvarnost, LIV, 9-10, 1027-1038.

Kodžopeljić, J. (2009). Procena vaspitnih stavova (VS-skala). U: M. Biro, S. Smederevac, Z. Novović (ur.), Procena psiholoških i psihopatoloških fenomena (165-178). Beograd: Centar za primenjenu psihologiju.

Majstorović, N., Kodžopeljić, J., Mirković, S. (1999). Povezanost vaspitnih stavova roditelja i konformizma njihove dece. Pedagoška stvarnost, MCXCIX (1-2), 109-123.

Matejević, M. (2007). Vrednosne orijentacije i vaspitni stil roditelja. Niš: Filozofski fakultet.

Matejević, M., i Todorović, J. (2012). Funkcionalnost porodičnih odnosa i kompetentno roditeljstvo. Niš: Filozofski fakultet.

Михић, И. (2005). Улога васпитних стилова родитеља у процени породице. У: М. Францешко и М. Зотовић (ур.), Личност у вишекултурном друштву 5 (238-255). Нови Сад: Филозофски факултет.

Mihić, I., Zotović, M., Petrović, J. (2006). Sociodemografske karakteristike porodice, podela posla u kući i vaspitni stilovi roditelja u porodicama na teritoriji Vojvodini. Pedagoška stvarnost, LII, 1-2, 118-134.

Mihić, I., Zotović, M., Jerković, I. (2006). Struktura i sociodemografski korelati porodične klime u Vojvodini. Psihologija, 39, 297-312.

Mihić, I., Čolović, P., Bodroža, B., Biro M. i Smederevac, S. (2009). Procena autoritarnosti (Upitnik AutoritarNoSt). U: M. Biro, S. Smederevac, Z. Novović, Z. (ur.), Procena psiholoških i psihopatoloških fenomena (153-164). Beograd: Centar za primenjenu psihologiju.

Milovanović, I. (2014). Uticaj postkonfliktnih društvenih promena na svakodnevni život žena na Kosovu i Metohiji - mogućnosti primene metode slučaja (nepublikovana doktorska disertacija). Filozofski fakultet, Univerzitet u Novom Sadu, Novi Sad.

Mitić, M. (2011). Deca sa smetnjama u razvoju, potreba i podrška. Beograd: Republički zavod za socijalnu zaštitu.

Opačić, G., Pjurkovska-Petrović, K., Ševkušić, S., Joksimović, S. (1995a). Uloga porodice u formiranju vrednosti kod mladića. Psihologija , 1-2, 109-122.

Opsenica-Kostić, J. (2012). Adolescenti i njihovi roditelji u svetlu PART teorije (nepublikovana doktorska disertacija). Univerzitet u Nišu, Filozofski fakultet. 
Павићевић, М. (2012). Повезаност васпитних ставова родитеља и ауторитарности адолесцената. Саопштење на 60. Научно-стручном скупу психолога Србије. Књига резимеа (159-160). Београд: Друштво психолога Србије.

Павићевић, М. и Томовић, И. (2012). Процењени васпитни ставови родитеља у односу на неке социодемографске карактеристике. У: Дани примењене психологије. Књига резимеа (138). Ниш: Филозофски факултет Универзитета у Нишу.

Павићевић, М. и Крстић, М. (2013). Васпитни ставови и задовољство породицом код студената. У: Б. Јовановић и М. Крстић (ур.), Појединаи, породица, друштво у транзициији (317-335). Косовска Митровица: Филозофски факултет.

Павићевић, М. и Минић, J. (2014). Васпитни ставови родитеља као предиктори селф-концепта младих. У: М. Крстић, Д. Ранђеловић, Г. Николић (ур.), Млади и друштвене промене: између националног идентитета и евроинтеграциија (309-325). Косовска Митровица: Филозофски факултет.

Павићевић, М. и Петровић, Д. (2016). Повезаност васпитних ставова родитеља и етноцентризма адолесцената. Зборник радова Филозофског факултета Унивеерзитета у Приштини, XLVI (1), 375-397.

Pavićević, M. i Stojiljković, S. (2016). Percipirani vaspitni stavovi roditelja kao prediktori interpersonalne orijentacije studenata. Primenjena psihologija, 9 (3), 293-311.

Pavićević, M. i Stoševski, A. (2019a). Vaspitni stilovi roditelja kao prediktori interpersonalne orijentacije i zadovoljstva životom kod adolescenata. 67. Kongres psihologa Srbije. Psihologija u novom dobu: izazovi (re)humanizacije. Knjiga rezimea (93-94). Zlatibor (22-25. maj).

Pavićević, M. i Stoševski, A. (2019b). Procenjeni vaspitni stilovi roditelja kao prediktori osobina ličnosti mladih. U: M. Nikolić i M. Vantić-Tanjić (ur.), Unapređenje kvalitete života djece i mladih. Tematski zbornik I dio (335354). Tuzla: Udruženje za podršku i kreativni razvoj djece i mladih Tuzla, Univerzitet u Tuzli Edukacijsko-rehabilitacijski fakultet.

Pavićević, M. i Stojiljković, S. (2019). Parenting styles as predictors of subjective well-being of adolescents. U: Psihološki, medicinski i obrazovni aspekti dobrobiti pojedinaca i grupa u procesu društvene tranzicije (13-34). Kosovska Mitrovica: Filozofski fakultet.

Павичевич, М. (2019). Родительские стили воспитания как предикторы самоэффективности подростков. Современное образование для изифовой экономики: новые вызовы и перспективы развития: сборник трудов Международной научной конференции, Россия, (г. Ростов-на-Дону, 13-15 мая 2019 г.). 
Piorkowska-Petrović, K. (1991). Jedan model za ispitivanje vaspitnih stavova roditelja. Psihologija, 24, 1-2, 170-179.

Pleck, J. \& Masciadrelli, B. (2004). Paternal Involvement by US residential fathers: levels, sources and consequences. In: Lamb M. (Ed.), The Role of the father in child development 4 (222-271). New York: Wiley.

Robinson, C. C., Mandleco, B., Olsen, S. F., Hart, C. H. (2001). The Parenting Styles and Dimensions Questionnaire (PSDQ). In: B. F. Perlmutter, J. Touliatos, G. W. Holden (Eds.). Handbook of family measurement techniques (319321). Sage: Instruments \& Index, Thousand Oaks.

Todorović, J. (2005). Vaspitni stilovi roditelja i samopoštovanje adolescenata. Niš: Prosveta.

Требјешанин, Ж. (2008). Представа о детету у српској култури. Београд: Софос.

Златановић, С. (2012). Однос етничког и групих одлика колективног итентитета: теренска истраживања српске заједнице на југоистоку Косова (необјављена докторска дисертација). Универзитет у Београду, Филозофски факултет.

Čudina-Obradović, M. i Obradović, J. (2006). Psihologija braka i obitelji. Zagreb: Golden marketing - Tehnička knjiga.

Шрам, 3. (2010). Етноцентризам, перцепција пријетње и хрватски наци-

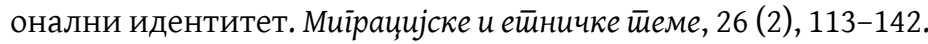

Зотовић, М., Михић, И., Петровић, J. (2008). Стресна искуства и њихов значај за формирање појма о себи у адолесценцији. Пеgаїошка сйварности, 3-4, 326-339.

\author{
МИљАНА С. ПАВИЋЕВИЋ \\ ЈЕЛЕНА Љ. МИНИЋ \\ УНИВЕРЗИТЕТ У ПРИШТИНИ СА ПРИВРЕМЕНИМ СЕДИШТЕМ \\ У КОСОВСКОЈ МИТРОВИЦИ, ФИЛОЗОФСКИ ФАКУЛТЕТ \\ КАТЕДРА ЗА ПСИХОЛОГИЈУ
}

РЕЗИМЕ

ВАСПИТНИ СТИЛОВИ РОДИТЕЉА АДОЛЕСЦЕНАТА НА КОСОВУ И МЕТОХИЈИ

У раду настојимо да приказом истраживања васпитних стилова родитеља, која су рађена на узорку адолесцената који живе или студирају на Косову и Метохији, укажемо на доминантни васпитни стил родитеља и предвидимо даљи развој неких карактеристика код адолесцената које су обухваћеним истраживањима испитиване. Такође, циљ нам је да укажемо на смер неких 
ठудућих истраживања ове проблематике и дамо основне препоруке за организовање превентивних и интервентних програма намењених родитељима, али и адолесцентима. Након увида у резултате приказаних истраживања (спроведених од 2012. до 2019. године) као доминантан васпитни стил родитеља испитаних адолесцената (више од 2.200 адолесцената тј. средњошколаца и студената, узраста од 16 до 24 године) издвојио се: хладно-ограничавајући васпитни стил као доминантан васпитни стил код очева у свим приказаним истраживањима. Код мајки поред хладно-ограничавајућег, издваја се и топло-ограничавајући васпитни стил. Увидом у истраживања васпитних стилова добијене су одређене корелације и разлике, као и резултати који указују на могућност предикције развоја одређених карактеристика адолесцената у зависности од васпитних стилова родитеља. Закључци који су проистекли из увида у истраживања, омогућили су конципирање одређених препорука за практичан рад и организовање неких ठудућих истраживања.

Препоруке за рад са родитељима односе се на: организовање едукације родитеља с циљем упознавања, али и усвајања квалитетнијих васпитних поступака. Едукацијом би требало обухватити и аспект комуникацијских вештина са циљем ефикасније комуникације и побољшања односа родитељ-адолесцент. Затим, препорука је организовање саветодавног рада са породицама, са циљем јачања капацитета за сарадњу са родитељима на плану васпитања деце и бриге о њима. Нарочито је важно организовање саветодавног рада са очевима, како би се повећао квантитет, али и квалитет њихове укључености у васпитању адолесцената. Када је у питању наставак истраживања, сматрамо значајним укључити и родитеље у истраживање, како би се омогућило поређење резултата из угла родитеља и њихове деце, тј. адолесцената, затим испитивање односа васпитних стилова и узраста, као и низа породичних варијабли.

КљУЧнЕ РЕЧи: васпитни стилови; родитељи; средњошколци; студенти.

Овај чланак је објављен и дистрибуира се под лиценцом Creative Commons Ауторство-Некомерцијално Међународна 4.0 (СC BY-NC 4.0 |

https://creativecommons.org/licenses/by-nc/4.0/).

This paper is published and distributed under the terms and conditions of the Creative Commons Attribution-NonCommercial International 4.0 licence (CC BY-NC 4.0 | https://creativecommons.org/licenses/by-nc/4.0/). 